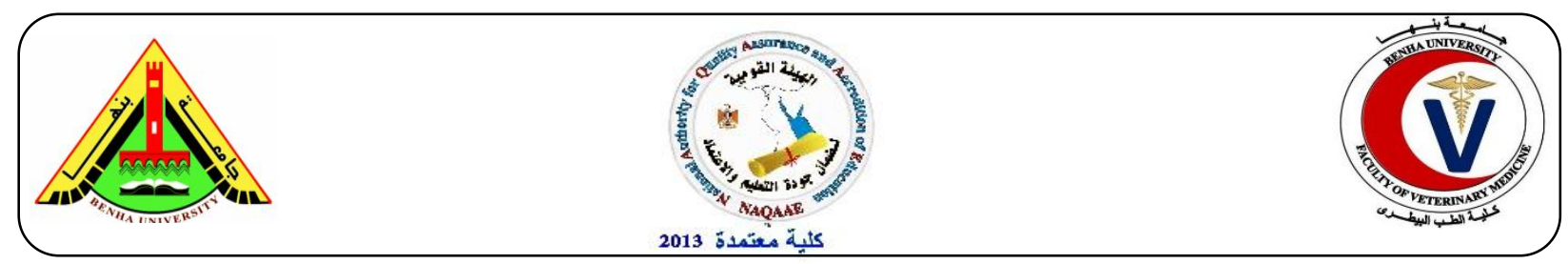

\title{
Assessment of irradiated Staphylococcus aureus isolates as a vaccine ${ }^{1}$ Inas M. Gamal; ${ }^{2}$ Sawsan M. El-Sonbaty; ${ }^{3}$ Hala Mahmoud; ${ }^{4}$ Hanaa A. Alam; ${ }^{5}$ Noha S.
}

\author{
Abdelkhalek \\ ${ }^{1}$ Immunity unit-Animal production research institute-5 mrkz bhoth alhdaik street-Alharam-Giza. ${ }^{2}$ Department of \\ Radiation microbiology, The National center for radiation research and technology (NCRRT), Atomic Energy \\ Authority. P. O. Box: 29 Nasr City, Cairo, Egypt. ${ }^{3}$ Central laboratory for Evaluation of veterinary Biologics- \\ alseka albeda-Abasia-Cairo-Egypt. ${ }^{4}$ Department of mastitis and neonatal disease- Animal production research \\ institute-5 mrkz bhoth alhdaik street-Alharam-Giza. ${ }^{5}$ Department of reproduction diseases-Animal production \\ research institute-5 mrkz bhoth alhdaik street-Alharam-Giza.
}

\section{A B S T R A C T}

Studies were initiated in an attempt to produce an inactivated vaccine of high potency with low toxicity. In this study structural integrity of bacteria can be preserved when different radiation doses of gamma rays were used to inactivate $S$. aureus. The results revealed that the $7 \mathrm{KGy}$ of $\gamma$-radiation was the most suitable dose for attenuation $S$. aureus. Moreover, this study demonstrated that exposure of $S$. aureus to $\gamma$-radiation at a dose of $7 \mathrm{KGy}$ inactivated bacterial cells growth with low DNA damage and did not alter bacteria protein profile. Meanwhile, higher radiation doses caused an obvious DNA damage and alteration in the bacterial protein profile. Furthermore, the effect of gamma irradiated $S$. aureus on the innate and adaptive immune components after vaccination was demonstrated. All the measured immunological parameters (TLR2, IL10, IL1 $\beta$, iNOs, TGF $\beta$, MAPK and PI3K) were increased when compared to the control group. This approach could expedite vaccine production for emerging and established pathogens for which no protective vaccines exist.

Keywords: Staphylococcus aureus, vaccine, gamma radiation

(BVMJ, 35 (2), 2018)

\section{INTRODUCTION}

Mastitis is the most devastating worldwide disease of dairy animals and of major economic threat to the dairy farmers (Seegers et al., 2003). It is an inflammatory disease that most commonly results from bacterial infection of the mammary gland (Osman et al., 2014). According to Blood and Radostits (1989), the economic losses from the decline of farm milk productivity due to mastitis, could reach $70 \%$. Staphylococcus aureus is the major cause of bovine mastitis when compared to other species of the Staphylococcus genus (Vasudevan et al., 2003). It is easily transmissible and responds poorly to treatment. Another facet of $S$. aureus pathogenesis is the organism's ability to maintain cellular homeostasis while enduring environmental challenges, such as changes in host cell temperature or exposure 
to phagocyte-mediated reactive temperature species (Voyich et al., 2005). Most of the mastitis was treated by antibiotics application, which is primarily eliminates bacteria. However, the uncontrolled use of antibiotics in the field may leads to new problems of the resistant pathogenic strains to antibiotics and drugs residue in milk (Chotiah, 1993).

Inactivated or attenuated bacterial vaccines are produced by killing the pathogens with chemical agents, heat, or radiation. Ionizing radiation (e.g., gamma rays and X-rays) was introduced for the vaccine development strategy since the early days of vaccinology (Elena et al., 2012).

The inactivation using different chemical compounds eventually leave some residues in the final products, further some are toxic while others cause allergic responses. However, it is possible that some bacteria may escape during the chemical inactivation routes. The bacterial inactivated vaccines using ionizing radiation are more stable, retain most of their antigenicity and safer than live vaccines. Also, the bacterial particles cannot escape from inactivation by gamma irradiation and they can be stored and transported in a freeze-dried form that makes them accessible to people in developing countries (Ho Seong Seo, 2015).

Gamma radiation is electromagnetic radiation of short wavelength emitted by radioactive isotopes as the unstable nucleus breaks up and decays to reach a stable form. Radiation technology has been used in the development of human and animal vaccines, because it can remove chemical contaminants and penetrate pathogens while preserving immunogenicity (Hewitson et al., 2005).

The major advantages of ionizing radiation in vaccine development compared to ultraviolet light or chemical agents are its ability to penetrate through most biological materials, and the fact that it targets both double and single stranded nucleic acids while causing less damage to surface antigenic proteins. Moreover, there is no need to remove any chemical residue after inactivation. Although the argument remains that irradiated vaccines elicit different immune responses than those generated by heat-killed or chemically killed methods, the demand for the application of gamma radiation is increasing for the development of safe vaccines (Magnani et al., 2009).

This work aim at assessment of irradiated Staphylococcus aureus isolates as a vaccine.

\section{MATERIAL AND METHODS}

\subsection{Collection of milk samples:}

A total number of 143 samples of bovine mammary secretions including 41 and 102 clinical and subclinical milk samples respectively (according to California Mastitis Test; CMT) were collected from mastitic cows in five different dairy herds from different localities in Egypt.

2.2. Bacterial strains and growing conditions (Isolation, phenotypic and genotypic identification):

Samples were cultured on mannitol salt agar (specific media), blood agar (for detection of haemolysis) and nutrient agar 
(Oxoid media). Isolates were identified biochemically by catalase, oxidase, urease tests, phosphatase test (Quinn et al., 2003), coagulase test (Koneman et al., 2005), sugar fermentation, nitrate reduction test (Cruickshank et al., 1975) and Ornithine decarboxylase test (Kloos et al., 1991). Final identification was done using APIStaph. kit (BioMerieux) according to manufactures instructions. Reference strains used for quality control were S. aureus ATCC 25213 and S. aureus ATCC 25923.

\subsection{PCR Identification of $S$. aureus} isolates by using $16 \mathrm{~S}$ rRNA gene:

The identification of $S$. aureus isolates was determined using PCR amplification with universal $16 \mathrm{~S}$ ribosomal RNA primers 8F T- 3' (Monday and Bohach, 1999 and Brakstad et al., 1992) as described by James et al., (2013). DNA was isolated from pure cultures using ZR Fungal/Bacterial DNA Mini Prep ${ }^{\mathrm{TM}}$ kit (ZYMO RESEARCH). Thermal cycling was performed using a Nexus gradient Master cycler (Eppendorf, Germany) as described previously: initial denaturation at $95^{\circ} \mathrm{C}$ for $4 \mathrm{~min}$, followed by 30 cycles of $94^{\circ} \mathrm{C}$ for 1 min (denaturation), $60^{\circ} \mathrm{C}$ for $45 \mathrm{~s}$ (annealing), $72^{\circ} \mathrm{C}$ for $1 \mathrm{~min}$ (extension), followed by a final extension cycle at $72^{\circ} \mathrm{C}$ for $4 \mathrm{~min}$, and a final hold at $4^{\circ} \mathrm{C}$. Amplimers of $16 \mathrm{~S}$ rRNA genes were purified using DNA Clean and Concentrator ${ }^{\text {TM}}-25 \quad$ kits $\quad$ (ZYMO RESEARCH) according to the manufacturer's recommendations and eluted DNA was stored at $-20^{\circ} \mathrm{C}$ until needed. DNA products were analyzed by running on gel electrophoresis.

Table (1): List of primers used in PCR

\begin{tabular}{|c|c|c|c|}
\hline $\begin{array}{l}\text { Primer } \\
\text { name }\end{array}$ & $\begin{array}{l}\text { Primer sequence 5'-3' } \\
\text { (reference) }\end{array}$ & $\begin{array}{l}\text { product } \\
\text { size }\end{array}$ & Specificity \\
\hline $\begin{array}{l}\text { 16SrRNA f } \\
\text { 16SrRNAr }\end{array}$ & $\begin{array}{l}\text { 5' GTA GGT GGC AAG CGTTAT CC 3' } \\
\text { 5' CGC ACA TCA GCG TCA G 3' }\end{array}$ & $228 \mathrm{bp}$ & $\begin{array}{l}\text { Staphylococcus } \\
\text { genus specific } \\
\text { primers }\end{array}$ \\
\hline $\begin{array}{l}\text { пис } 1 \\
\text { пис } 2\end{array}$ & $\begin{array}{l}\text { 5'-GCGATTGATGGT GATACGGTT-3' } \\
\text { 5'-AGCCAAGCCTTGACGAACTAAAGC-3' }\end{array}$ & $279 \mathrm{bp}$ & $\begin{array}{l}\text { S. aureus } \\
\text { specific primers }\end{array}$ \\
\hline
\end{tabular}

\begin{tabular}{lll}
\hline Gene symbol & Primer sequence 3-5 & $\begin{array}{l}\text { Gene } \\
\text { accession no. }\end{array}$ \\
\hline TLR2 & 5'-TGTTTGCTCCTGCGAACTCCTA-3' & XM_008761102.2 \\
& 5'-AGCCTGGTGACATTCCAAGACG-3' & \\
\hline iNOS & 5'-TAAAGGGACAGCGTCAGCGA-3' & XM_006246949.3 \\
& 5'-TGGGGGAACACAGTAATGGC-3' & \\
\hline b-actin & 5'-TGTTGTCCCTGTATGCCTCT-3' & NM_031144.3 \\
& 3'-TAATGTCACGCACGATTTCC-5' & \\
\hline
\end{tabular}




\subsection{Gamma radiation facility:}

Irradiation treatments of $\mathrm{S}$. aureus grown on TGY agar plates were performed by using Cobalt 60 Indian Gamma cell; The National Center for Radiation Research and Technology, Atomic Energy Authority, Cairo, Egypt, at room temperature (25 \pm $\left.2^{\circ} \mathrm{C}\right)$. Samples were irradiated at 4, 5, 6, 7, 8 and $9 \mathrm{KGy}$ in the gamma cell with a dose rate of $1.19 \mathrm{kGy} / \mathrm{h}$.

\subsection{Protein determination:}

2.5.1. Preparation of $S$. aureus sample for PAGE:

Bacteria isolates cultured in Brain heart infusion (BHI) broth and subjected to gamma irradiation, Immediately after irradiation $500 \mathrm{ml}$ of each bacterial culture were quickly chilled in an ice / ethanol bath until the temperature dropped below $10^{\circ} \mathrm{C}$. Cells were harvested by centrifugation at $10,000 \mathrm{~g}$ for 10 minutes at $4^{\circ} \mathrm{C}$ and the resulting pellet was washed in $10 \mathrm{ml}$ of phosphate buffer saline $\mathrm{pH} 7.4$ and diluted by phosphate buffer saline to $1.5 \mathrm{ml} / \mathrm{v}$. Cell suspension was sonicated for 3 minutes at level 4, then centrifuged at $11.000 \mathrm{~g}$ for 3 minutes. Supernatant obtained was taken and stored at $0-4^{\circ} \mathrm{C}$ (Tuasikal et al., 2012).

\subsubsection{Sodium Dodecyl Sulphate- \\ Polyacrylamide \\ Gel \\ Electrophoresis (SDS-PAGE):}

The cellular protein extracts were denatured and separated in $10 \%$ sodium dodecyl sulphate-30\% polyacrylamide separating gel electrophoresis according to the method of Laemmli, (1970). Using mini-protein II electrophoresis cell (BioRad) at 50 volts for 4 hrs. The electrophoretic patterns of the structural bacterial proteins were matched with the full-range molecular weight protein marker ranging from 3.5 to $240 \mathrm{KDa}$ (Gene Direx, Cat. No. PM008-0500).

2.6. Single cell gel electrophoresis (Comet Assay):

Single cell gel electrophoresis or Comet assay is a simple, sensitive and rapid method for the detection of DNA damage (Singh et al., 1988). Slides were prepared in duplicate per group and the test was performed for at least 3 different bacterial cells samples from each group. For the cell suspension, approximately $4 \times 10^{6}$ cells were mixed with $80 \mu \mathrm{l}$ of $0.7 \%$ low-melting agarose in phosphate buffered saline (PBS) at $37^{\circ} \mathrm{C}$ in a microtube, and then spread over a window microscopic slide. The slides were preloaded with $150 \mu \mathrm{l}$ of $0.5 \%$ lowmelting agarose in PBS and were specially designed for this assay. The slides were immediately placed in cold lysis buffer containing $2.5 \mathrm{M}$ sodium chloride $(\mathrm{NaCl})$, $100 \mathrm{mM}$ EDTA sodium salt $\mathrm{Na}$ EDTA,10mM Tris (pH 10), and 1\% Triton $\mathrm{X}-100$, at $4^{\circ} \mathrm{C}$ for a minimum of $1 \mathrm{hr}$. After lysis, the slides were drained and placed in a horizontal gel electrophoresis tank placed in ice and filled with fresh cold electrophoresis buffer $(300 \mathrm{mM}$ sodium hydroxide $(\mathrm{NaOH})$, $1 \mathrm{mM}$ Na EDTA, pH 13). To allow uncoiling of DNA, the slides were kept in the high PH buffer for 20 minutes. Subsequently, electrophoresis was carried out for 20 minutes at $25 \mathrm{~V}$ and $300 \mathrm{~mA}$. The slides were then drained and flooded slowly with 3 changes of neutralization buffer (0.4M Tris, $\mathrm{pH} 7.5$ ) for 5 minutes each and then stained with $30 \mathrm{ml}$ of ethidium bromide $(20 \mathrm{mg} / \mathrm{l})$ and covered with cover 
slips. All those steps were performed under dimmed light to prevent additional DNA damage caused by visible light. A total of 50 randomly selected cells per slide were analyzed. Imaging was performed with a fluorescence microscope (Zeiss Axiovert L410 Inc., Jena Germany), attached to a digital camera (Olympus Inc., Tokyo, Japan), and equipped with a $549 \mathrm{~nm}$ excitation filter, and a $100-\mathrm{W}$ mercury lamp. The percentage of DNA in the comet tail (DNA damage) was automatically calculated using a 'Toolbox' from the IN cell Investigator analysis package (GE Healthcare Life Sciences), Tail moment was calculated as a product of tail length multiplied by tail \% damage.

\subsection{Mice inoculation:}

Forty female mice of $30 \pm 5$ gm body weight, and 4-6 weeks age were divided into 5 groups (8 mice per each group) and non-infected group considered as a control group. Four groups were inoculated i/p with $0.25 \mathrm{ml} /$ of irradiated and nonirradiated $S$. aureus $(0,7,8$ and $9 \mathrm{KGy})$ for three times with one-week interval and the mice were bled 14 days after the third booster (Dane Parker 2017).

\subsection{Experimental protocol (Morton et al 1970):}

Studies investigating the pathogenesis of $S$. aureus infection have relied heavily on the use of mouse models. Mice have been used to understand the role of virulence factors play during infection as well as the contribution of specific host pathways and factors in the response to $S$. aureus.

After an acclimatization period of 7 days, mice were randomly allocated and divided into five equally sized groups, ten animals each, as follows: Group I, mice, kept as controls, received daily i/p. $1 \mathrm{ml}$ of physiological saline. Group II, mice received non-irradiated $S$. aureus at a dose of $1 \times 10^{6}$ cells. Group III, mice were injected with $0.1 \mathrm{ml}$ of irradiated (7 KGy) S. aureus $\mathrm{i} / \mathrm{p}$. at a dose of $1 \times 10^{6}$ cell. Group IV, mice were $\mathrm{i} / \mathrm{p}$. injected with $0.1 \mathrm{ml}$ of irradiated (8 KGy) S. aureus at a dose of $1 \times 10^{6}$ cells and Group V, mice were i/p. injected with $0.1 \mathrm{ml}$ of irradiated (9 KGy) $S$. aureus at a dose of $1 \times 10^{6}$ cell. The mice were injected once /week for 3 times and sacrificed 7 days after the last injection and blood samples were collected from all groups.

\subsection{Biochemical assays (Borreham et al., 2000):}

The quantitative determinations of mice interleukin -6 (IL-6), interleukin -1 $\beta$ (IL-1 $\beta$ ) and Tumor growth factor (TGF- $\beta$ ) concentrations in serum were carried out using mice ELISA kits (R\&D Systems and MyBioSource).

2.10. Western blotting of MAPK and Phosphoinositide 3-kinases (pi3K):

Liver tissue proteins were extracted using TRIzol reagent (Invitrogen) according to Chomczynski (1993), and protein concentrations were quantified according to Bradford (1976). The membranes were developed and visualized by chemiluminescence using Amersham detection kit according to the manufacturer's protocols and then exposed to X-ray film. Quantification of MAPK and pi3K proteins was carried out using a scanning laser densitometer analysis (Biomed Instrument Inc., USA). 
2.11. RNA extraction and cDNA synthesis:

To investigate the changes in mRNA expression for TLR2 and iNOS genes, total RNA was isolated from 50mg liver using TRIzol reagent (Invitrogen) according to Chomczynski (1993). First-strand complementary DNA (cDNA) synthesis was performed using reverse transcriptase (Invitrogen) throughout template $1 \mu \mathrm{g}$ RNA.

\subsection{Quantitative}

real-time

polymerase chain reaction $(q P C R)$ :

RT-PCR was performed in a thermal cycler Step One Plus (Applied Biosystems, USA) using the Sequence Detection Software (PE Biosystems, CA). A reaction mixture of total volume $25 \mu \mathrm{l}$ consists of $2 \times$ SYBR Green PCR Master Mix (Applied Biosystems), $900 \mathrm{nM}$ of each primer (TLR2 and iNOS), and $2 \mu \mathrm{l}$ of cDNA. PCR thermal cycling conditions included an initial step at $95{ }^{\circ} \mathrm{C}$ for $5 \mathrm{~min}$ and 40 cycles at $95{ }^{\circ} \mathrm{C}$ for $20 \mathrm{~s}, 60{ }^{\circ} \mathrm{C}$ for $30 \mathrm{~s}$, and $72^{\circ} \mathrm{Cfor} 20 \mathrm{~s}$. The relative mRNA expression of the studied genes was calculated using the comparative threshold cycle method of Pfaffl (2001).

\subsection{Statistical analysis:}

All determinations were done in triplicate. Statistical analysis was done using SPSS (version 20) program. Mean and standard error were descriptive measures of quantitative data using the analysis of variance test (ANOVA) for independent samples.

\section{RESULTS}

\subsection{Identification of bacteria isolates by} multiplex PCR:
Identification of bacterial isolates using $\mathrm{m}$-PCR identified bacteria isolates as Staphylococcus aureus. M-PCR results were analyzed using agarose gel electrophoresis showed two bands positive amplification of $228 \mathrm{bp}$ specific for the Genus Staphylococcus, and positive at an amplification of 279 bp specific for $S$. aureus.

\subsection{Effect of gamma rays on $S$. aureus:}

Preliminary tests were conducted to determine the lethal doses of irradiation for S. aureus. Attenuation of bacterial isolates was achieved by exposure to different doses of gamma radiation (4-9 KGy) to study the effect of gamma rays on bacterial cells viability, protein profile and DNA.

3.3. Effect of gamma rays on $S$. aureus protein profile:

\subsubsection{Electrophoretic protein profile using SDS-PAGE analysis:}

Samples of suspended $S$. aureus were exposed to different doses of $\gamma$ - radiation (4, 5, 6, 7, 8 and $9 \mathrm{KGy})$. All bacteria samples were inoculated on nutrient agar plates and recorded no bacterial growth at $5 \mathrm{KGy}$. Extracted bacterial proteins were analyzed using SDS-PAGE analysis. The results showed that protein profile of irradiated $S$. aureus at doses of 4 to $7 \mathrm{GKy}$ showed no alterations in the protein profile in comparison to the control of non-irradiated S. aureus. Meanwhile, an obvious alteration in the bacterial protein profile of irradiated $S$. aureus at doses of 8 and 9 GKy was revealed by SDS-PAGE analysis (Table 2) and Fig. (1). 


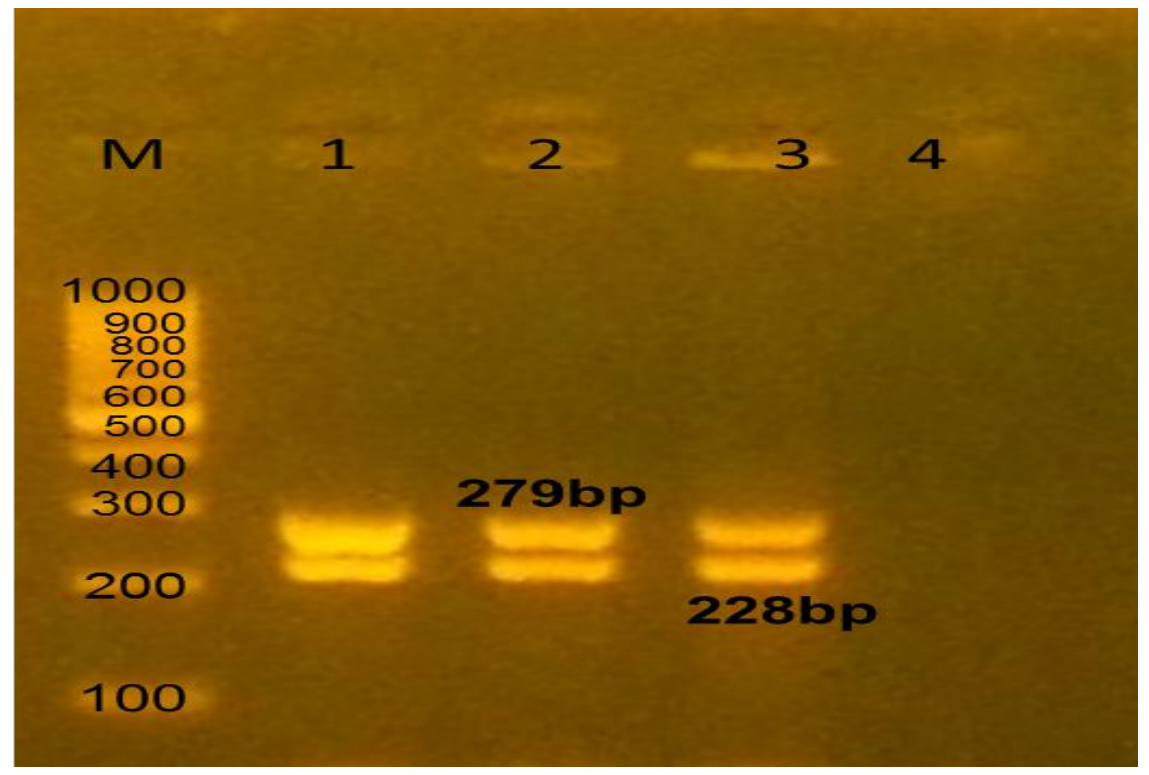

Figure.1 Identification of $S$. aureus isolates by multiplex polymerase chain reaction Lane M: 100bp marker.

Lane 1: Amplification of 228 and $279 \mathrm{bp}$ fragment of $S$. aureus local strain sample.

Lane 2: Positive control of $S$. aureus (ATCC 25213) DNA.

Lane 3: Positive control of $S$. aureus (ATCC 25923) DNA.

Lane 4: Negative control (without DNA).

Table (2): Electrophoretic protein pattern of $\gamma$-irradiated Staphylococcus aureus.

\begin{tabular}{cccccccccccccc}
\hline Marker & Control & \multicolumn{10}{c}{ Gamma radiation Dose (KGy) } \\
\cline { 3 - 16 } KD & $($ OKGy) & 4 & 4 & 5 & 5 & 6 & 6 & 7 & 7 & 8 & 8 & 9 & 9 \\
\hline 240 & 247 & 241 & 241 & 239 & 239 & 241 & 242 & 242 & 242 & - & - & - & - \\
165 & 203 & 216 & 216 & 216 & 216 & 216 & 216 & 216 & 216 & 216 & 216 & 216 & 216 \\
125 & 195 & 195 & 195 & 195 & 195 & 195 & 195 & 195 & 195 & 195 & 195 & 195 & 195 \\
92 & 128 & 128 & 128 & 128 & - & 128 & 128 & 128 & 128 & - & - & - & - \\
72 & 122 & 122 & 122 & 122 & 122 & 122 & 122 & 122 & 122 & 122 & 122 & - & - \\
57 & 116 & 116 & 116 & 116 & 116 & 116 & - & 116 & 116 & - & - & - & - \\
42 & 114 & 114 & 114 & 114 & - & 114 & 114 & 114 & 114 & 114 & 114 & - & - \\
31 & 84 & 84 & 84 & 84 & 84 & 84 & - & 84 & 84 & 84 & 84 & - & - \\
24 & 77 & 77 & 77 & 77 & 77 & 77 & 77 & 77 & 77 & - & - & - & - \\
18 & 59 & 59 & 59 & 59 & 59 & 59 & 59 & 59 & 59 & - & 59 & - & - \\
15 & 55 & 55 & 55 & 55 & 55 & 55 & 55 & 55 & 55 & 55 & 55 & - & - \\
8 & 41 & 41 & 41 & 41 & 41 & 41 & 41 & 41 & 41 & - & - & - & - \\
3.5 & 37 & 37 & 37 & 37 & 37 & 37 & 34 & 34 & 34 & - & - & - & - \\
\hline
\end{tabular}

3.4. Effect of $\gamma$-radiation on $S$. aureus DNA:

\subsubsection{Comet Assay:}

The DNA damage of $S$. aureus exposed to different doses of $\gamma$-rays was analyzed quantitatively by comet assay. The typical DNA comet for the control S. aureus showed almost rounded nuclei Figure (3a). The irradiated samples of $S$. aureus at 7 KGy (Figure 3b) showed nuclei of bright 
head with no tail which means there was no DNA damage in S.aureus cells. On the other hand, a typical DNA damage was shown for $S$. aureus samples exposed to 9GKy of gamma rays, the cells appeared to have small head with long diffused tail (Figure 3 c). The DNA damage in $S$. aureus cells exposed to different doses of $\gamma$ - rays was expressed as \% of DNA damage, tail moment (TM) and tail length (TL) (Table 3, Fig. 3).

Comet assay results showed that nonirradiated S.aurues have small tail length
$(16.5 \pm 6.7)$ and low percentage of DNA damage $(10.8 \pm 2.1)$. Exposing S.aurues to different doses of gamma rays induced DNA damage, which increases in proportion to gamma rays doses. The results showed that, changes caused in the DNA by gamma radiation in S.aureus cells was moderate at dose of $7 \mathrm{KGy}$ which showed tail length $(41.18 \pm 17.1)$ with percentage of damage $(49.33 \pm 2.3)$ in comparison to control. While, high percentage of DNA damage $(59 \pm 4.5)$ and maximum tail length $(37.9 \pm 29.3)$ induced by gamma radiation at a dose of $9 \mathrm{KGy}$.

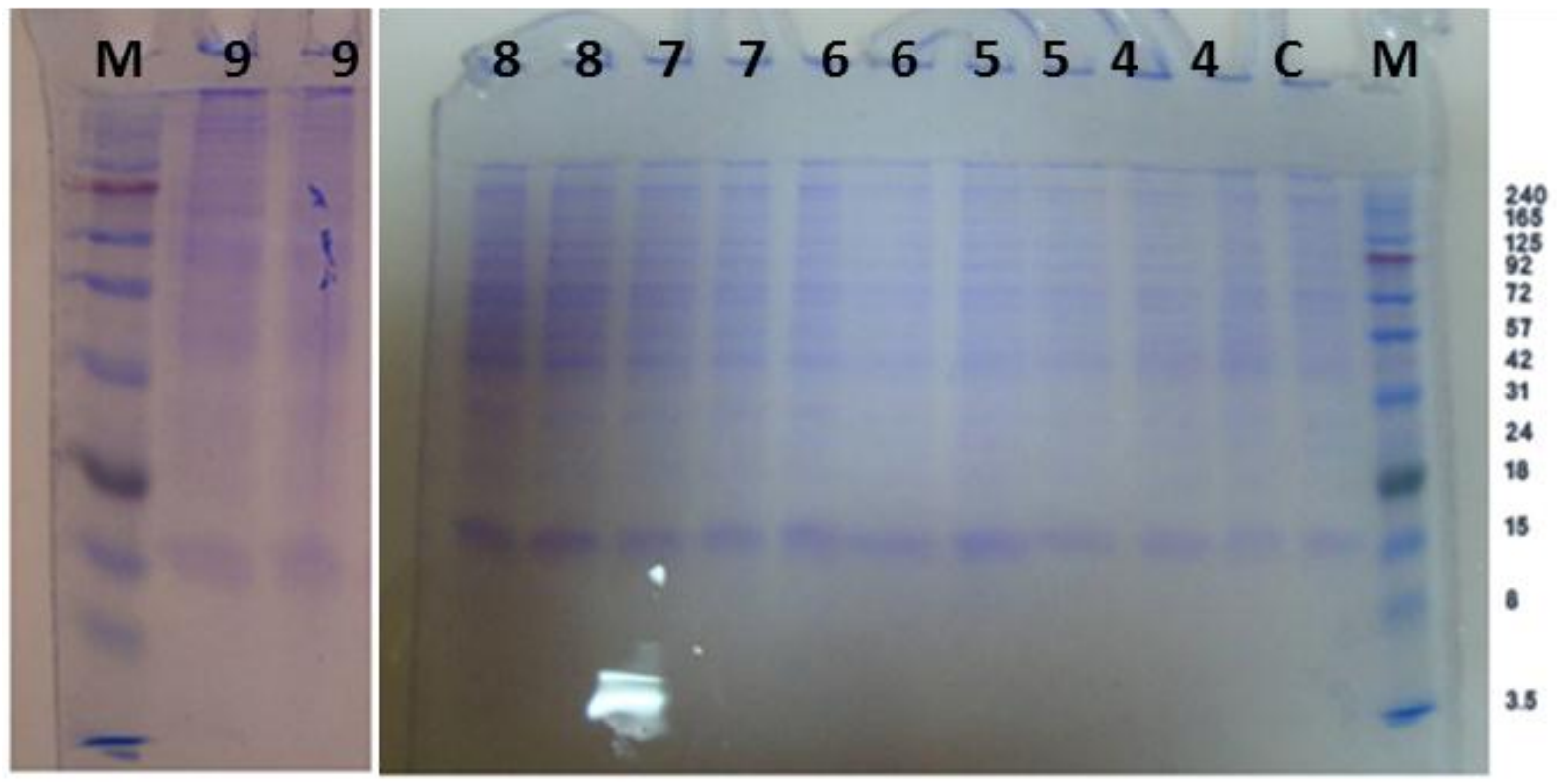

Figure (2): SDS-PAGE electrophoresis of S. aureus protein profile pattern after exposure to $\gamma$ radiation.

Lane M : Marker protein molecular weight: $3.5-240 \mathrm{kDa}$.

Lane C : Control S. aureus non-irradiated.

Lane $4:$ : S. aureus exposed to $\gamma$-radiation dose of $4 \mathrm{KGy}$.

Lane $5:$ : S. aureus exposed to $\gamma$-radiation dose of $5 \mathrm{KGy}$.

Lane 6: S. aureus exposed to $\gamma$ - radiation dose of $6 \mathrm{KGy}$.

Lane 7: $S$. aureus exposed to $\gamma$-radiation dose of $7 \mathrm{KGy}$.

Lane 8: $S$. aureus exposed to $\gamma$-radiation dose of $8 \mathrm{KGy}$.

Lane 9: $S$. aureus exposed to $\gamma$-radiation dose of $9 \mathrm{KGy}$. 

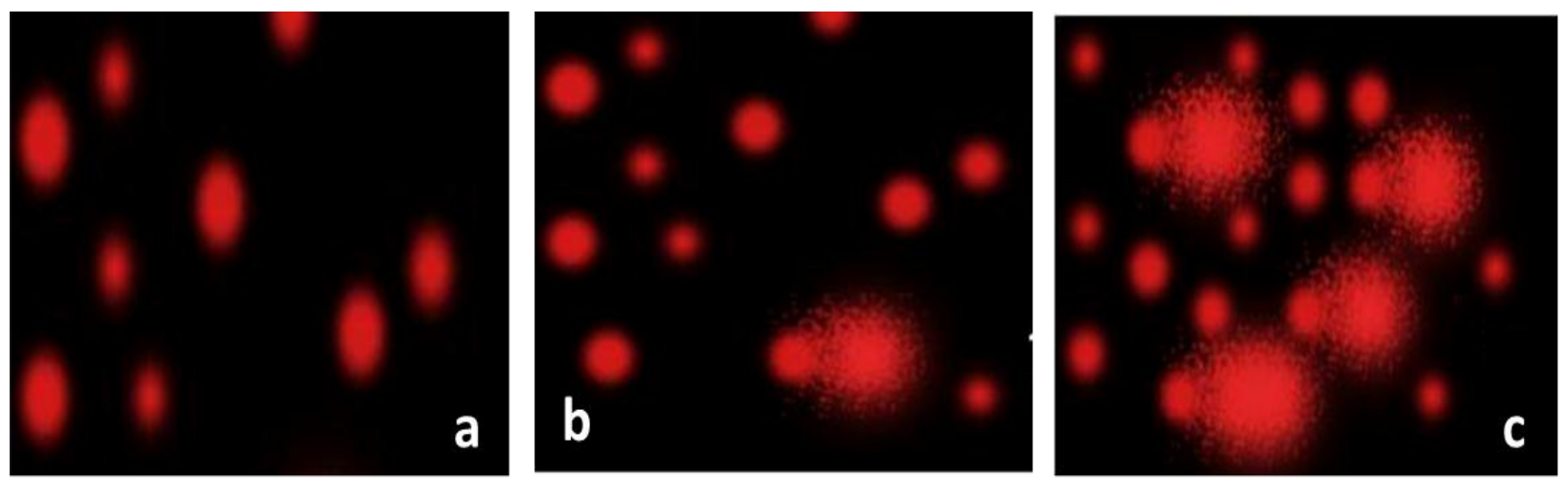

Figure (3). Typical fluorescence microscope images (comets). a: control, non-irradiated (0 KGy) S. aureus, b: $S$. aureus exposed to gamma radiation at a dose of $7 \mathrm{KGy}$, c: $S$. aureus cells exposed to gamma radiation at a dose of $9 \mathrm{KGy}$

Table (3): Comet analysis of DNA breakage of $S$. aureus cells exposed to $\gamma$-radiation.

\begin{tabular}{cccc}
\hline $\begin{array}{c}\text { Gamma radiation } \\
\text { dose (KGy) }\end{array}$ & $\begin{array}{c}\text { \% of DNA } \\
\text { Damage }\end{array}$ & Tail Moment & $\begin{array}{c}\text { Tail Length } \\
(\mu \mathrm{m})\end{array}$ \\
\hline Control (0) & $10.8 \pm 2.1$ & $1.15 \pm 0.03$ & $16.5 \pm 6.7$ \\
5 & $48.66 \pm 3.2^{\mathrm{a}}$ & $2.77 \pm 0.85^{\mathrm{a}}$ & $37.57 \pm 15.2^{\mathrm{a}}$ \\
6 & $44.00 \pm 1.9^{\mathrm{a}}$ & $2.85 \pm 0.67^{\mathrm{a}}$ & $40.58 \pm 16.9^{\mathrm{a}}$ \\
7 & $49.33 \pm 2.3^{\mathrm{a}}$ & $2.91 \pm 0.92^{\mathrm{a}}$ & $41.18 \pm 17.1^{\mathrm{a}}$ \\
8 & $56.00 \pm 3.6^{\mathrm{a}}$ & $4.33 \pm 0.98^{\mathrm{a}}$ & $58.72 \pm 23.3^{\mathrm{a}}$ \\
9 & $59.00 \pm 4.5^{\mathrm{a}}$ & $5.45 \pm 1.20^{\mathrm{a}}$ & $73.90 \pm 29.3^{\mathrm{a}}$ \\
\hline
\end{tabular}

Results are represented as mean \pm SE. ${ }^{\mathrm{a}}$, significant to control $(\mathrm{p}<0.05)$.

3.5. Effect of $\gamma$--irradiated $S$. aureus on the immune system of mice:

The innate and adaptive immune responses are key components of host responses after vaccination. Herein the pattern of innate immune response to $S$. aureus inoculation was demonstrated in Fig. (4).

3.6. The effect of $S$. aureus inoculation on TLR2 and iNOs relative gene expression/ $\beta$ actin:

The TLR2 and iNOs relative gene expression $/ \beta$ actin were analysed in the liver tissue using RTqPCR. Inoculation of mice with $S$. aureus markedly induced transcript level of TLR2 mRNA almost four folds compared to the control group. Mice challenged with non-irradiated, irradiated $S$. aureus at 7,8 and $9 \mathrm{KGy}$ induced alteration in the transcript level of TLR2 mRNA recording 4.65, 4.61, 6.37 and 8.22 respectively (Table 4 and Fig.4)

In the other hand, iNOs mRNA transcript level was significantly elevated almost six folds in mice inoculated with $S$. aureus compared to the control. The transcript mRNA level of iNOs in mice injected with non-irradiated, irradiated $S$. aureus at 7, 8 and $9 \mathrm{KGy}$ was significantly increased to be $6.49,6.85,6.18$ and 6.42 , respectively (Table 4 and Fig.4) 
Table (4): Effect of $\gamma$-irradiated Staphylococcus aureus inoculation on the immune system.

\begin{tabular}{|c|c|c|c|c|c|c|c|}
\hline Group & $\begin{array}{l}\text { TLR2 } \\
\text { gene } \\
\text { expression } \\
/ \beta \text {-actin }\end{array}$ & $\begin{array}{l}\text { iNOs } \\
\text { gene } \\
\text { expression } \\
/ \beta \text {-actin }\end{array}$ & $\begin{array}{l}\text { IL-10 } \\
(\mathrm{pg} / \mathrm{ml})\end{array}$ & $\begin{array}{l}\text { IL-1 } \beta \\
(\mathrm{pg} / \mathrm{ml})\end{array}$ & $\begin{array}{l}\text { TGF- } \beta 1 \\
(\mathrm{pg} / \mathrm{ml})\end{array}$ & $\begin{array}{l}\text { MAPK } \\
\text { Relative } \\
\text { intensity/ } \\
\beta \text { actin }\end{array}$ & $\begin{array}{l}\text { Pi3K } \\
\text { Relative } \\
\text { intensity/ } \\
\beta \text { actin }\end{array}$ \\
\hline Control & $\begin{array}{l}1.0 \pm \\
0.01^{\mathrm{b}}\end{array}$ & $\begin{array}{l}1.0 \pm \\
0.0^{\mathrm{b}}\end{array}$ & $\begin{array}{l}133.45 \\
\pm 10.73^{b}\end{array}$ & $\begin{array}{l}25.03 \pm \\
1.07^{\mathrm{b}}\end{array}$ & $\begin{array}{l}42.85 \pm \\
4.54^{\mathrm{b}}\end{array}$ & $\begin{array}{l}1.0 \pm \\
0.01^{b}\end{array}$ & $\begin{array}{l}1.0 \pm \\
0.01^{b}\end{array}$ \\
\hline $\begin{array}{l}\text { Non- } \\
\text { irradiated } \\
0 \mathrm{KGy}\end{array}$ & $\begin{array}{l}4.65 \pm \\
0.20^{\mathrm{a}}\end{array}$ & $\begin{array}{l}6.49 \pm \\
0.59^{\mathrm{a}}\end{array}$ & $\begin{array}{l}91.87 \\
\pm 9.54^{\mathrm{a}}\end{array}$ & $\begin{array}{l}108.47 \pm \\
9.87^{\mathrm{a}}\end{array}$ & $\begin{array}{l}75.47 \pm \\
8.64^{\mathrm{a}}\end{array}$ & $\begin{array}{l}1.11 \pm \\
0.02^{\mathrm{a}}\end{array}$ & $\begin{array}{l}1.27 \pm \\
0.1 \mathrm{a}\end{array}$ \\
\hline 7 KGy & $\begin{array}{l}4.61 \pm \\
0.20^{\mathrm{a}}\end{array}$ & $\begin{array}{l}6.58 \pm \\
0.32^{\mathrm{a}}\end{array}$ & $\begin{array}{l}82.02 \\
\pm 10.79^{a}\end{array}$ & $\begin{array}{l}108.6 \pm \\
15.8^{\mathrm{a}}\end{array}$ & $\begin{array}{l}111.77 \pm \\
13.43^{\mathrm{ab}}\end{array}$ & $\begin{array}{l}1.26 \pm \\
0.05^{\mathrm{ab}}\end{array}$ & $\begin{array}{l}3.52 \pm \\
0.2^{\mathrm{ab}}\end{array}$ \\
\hline $8 \mathrm{KGy}$ & $\begin{array}{l}6.37 \pm \\
0.19^{\mathrm{ab}}\end{array}$ & $\begin{array}{l}6.18 \pm \\
0.64^{\mathrm{a}}\end{array}$ & $\begin{array}{l}90.97 \pm \\
8.63^{\mathrm{a}}\end{array}$ & $\begin{array}{l}1 \Upsilon 2.2 \pm \\
10.95^{\mathrm{a}}\end{array}$ & $\begin{array}{l}108.07 \pm \\
10.95^{\mathrm{ab}}\end{array}$ & $\begin{array}{l}1.38 \pm \\
0.06^{\mathrm{ab}}\end{array}$ & $\begin{array}{l}5.38 \pm \\
0.4^{\mathrm{ab}}\end{array}$ \\
\hline $9 \mathrm{KGy}$ & $\begin{array}{l}8.22 \pm \\
0.19^{\mathrm{ab}}\end{array}$ & $\begin{array}{l}6.42 \pm \\
0.80^{\mathrm{a}}\end{array}$ & $\begin{array}{l}\wedge \circ .08 \pm \\
8.89^{\mathrm{a}}\end{array}$ & $\begin{array}{l}1 \Upsilon 0.75 \pm \\
9.87^{\mathrm{a}}\end{array}$ & $\begin{array}{l}124.18 \pm \\
13.54^{\mathrm{ab}}\end{array}$ & $\begin{array}{l}1.26 \pm \\
0.04^{\mathrm{ab}}\end{array}$ & $\begin{array}{l}5.8 \pm \\
0.5^{\mathrm{ab}}\end{array}$ \\
\hline
\end{tabular}

The results are represented as the mean $\pm \mathrm{SE}$, where $\mathrm{n}=6$. Where, a: the results are significant $(\mathrm{p}<0.05)$ compared to control group, b: results are significant $(\mathrm{p}<0.05)$ compared to group infected with non-irradiated Staph. aureus.

TLR2: toll like receptor

IL10: interleukin 10

TGF $\beta$ : transforming growth factor Beta Pi3K: phosphoinositide 3 kinase
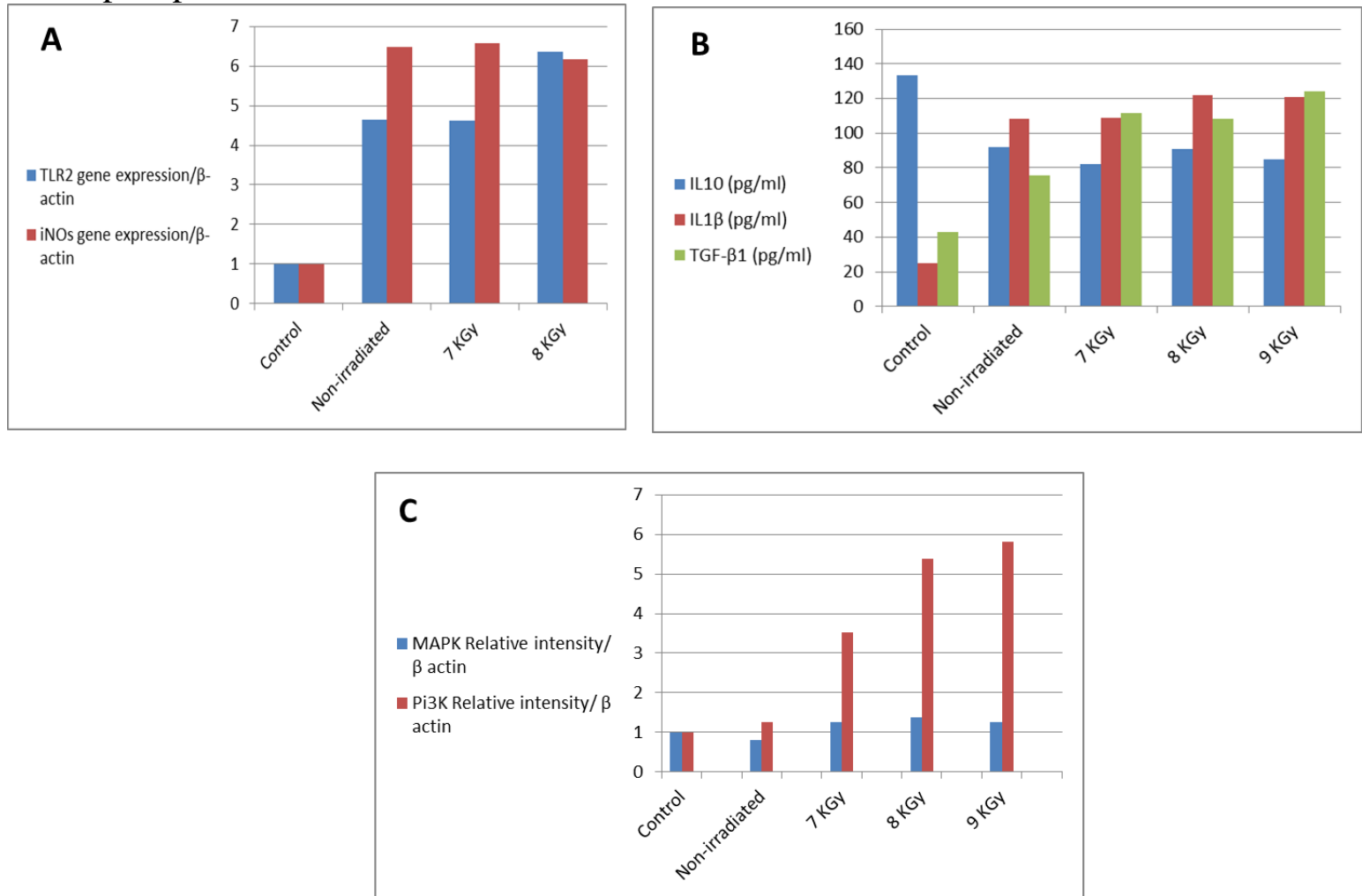

Figure (4): Staphylococcus aureus inoculation in female mice activating the immune system. 
3.7. The effect of $S$. aureus inoculation on inflammatory parameters: IL-10 and IL-1 $\beta$ levels:

Disturbance in the pro- and antiinflammatory cytokines balance eventually results in an exaggerated inflammatory response, multiple organ dysfunction syndrome, and septic shock. Therefore, the cytokine response to $S$. aureus infection in mice was examined.

Cytokine IL-10 is an immunological and anti-inflammatory parameter which was significantly reduced with bacterial infection compared to the control group. IL10 level in the mice serum was significantly decreased showing a level of $91.87,82.02$, 90.97 and $85.05 \mathrm{pg} / \mathrm{ml}$ in challenged mice previously inoculated with $S$. aureus of nonirradiated, irradiated at 7,8 and $9 \mathrm{KGy}$, respectively (Table 4 and Fig. 4).

Inoculation of radiation killed $S$. aureus induced IL- $1 \beta$ and TGF- $\beta 1$ level in mice serum. While, IL-10 concentration was significantly elevated about 4 folds to reach $108.47,108.60,122.2$ and 120.75 $\mathrm{pg} / \mathrm{ml}$ of serum in mice previously inoculated with $S$. aureus of non-irradiated, irradiated at 7, 8 and $9 \mathrm{KGy}$ respectively. TGF- $\beta 1$ level was raised almost double in response to non-irradiated $S$. aureus inoculation. While inoculation with irradiated killed bacterial cells elevated TGF- $\beta 1$ concentration to 3 folds to be $111.77,108.07$ and $124.18 \mathrm{pg} / \mathrm{ml}$ in mice injected with bacterial cells exposed to 7,8 and 9 KGy respectively.

3.8. Effect of $S$. aureus inoculation on protein intensity of MAPK, Pi3K relative to $\beta$-catenin
After ligation of TLR2 or NOD2 to $S$. aureus pathogenic factors that activates the gene expressions of MAPK signaling pathway including extracellular PI3K/Akt signaling pathway, and accounting for the production of the downstream cytokines

MAPK and Pi3K proteins relative intensity was significantly increased in response to inoculation with $S$. aureus compared to control group. Western blotting analysis of MAPK showed significant increase in mice inoculated with non-irradiated, irradiated at dose of 7, 8 and $9 \mathrm{KGy}$ to be $0.8,1.26,1.38$ and 1.26 respectively. Pi3K level of protein intensity was significantly elevated with MAPK level. Mice inoculated with non-irradiated, irradiated at a dose of 7.8 and 9 KGy. In the same line Pi3K level was increased from 1.27 in the group infected with nonirradiated bacteria to be $3.52,5.38$ and 5.8 in mice challenged with $S$. aureus irradiated at doses of 7, 8 and 9 KGy respectively (Table 4 and Fig. 4).

A relative level of TLR2 and iNOs mRNA expressions were analyzed by quantitative real-time polymerase chain reaction (RTqPCR); values were rectified by mRNA expression of $\beta$-actin for each sample, compared with non-infected mice. B: Quantitative analysis by Eliza of TGF$\beta 1, \mathrm{IL}-1 \beta$ and IL-10. C: relative intensity of PI3K and MAPK protein / $\beta$-actin using western blotting (Table 4 and Fig. 4). 


\section{DISCUSSION}

During radiation treatment, DNA molecules are heavily damaged, preventing them from functioning normally. Bacterial cells exposed to radiation will be affected in different ways: arrest cell cycle progression and repair of DNA lesions (Lee et al., 2010).

In this study, we have developed an attenuated radio-vaccine of $S$. aureus using gamma radiation at a dose of $7 \mathrm{kGy}$, which act as an immunostimulator to the infected host without molecular adverse and good safety.

During development of irradiated vaccine, SDS-PAGE of proteins normally reveals information on the electrophoretic pattern of the irradiated samples (Dosselli et al., 2012).

SDS-PAGE showed that minor changes were found in the protein profile of irradiated bacterial strain up to the dose of 7 $\mathrm{KGy}$, and major changes were appeared at higher doses of 8 and $9 \mathrm{KGy}$, indicating that S. aureus was inactivated by $7 \mathrm{KGy}$ irradiation dose by inhibiting its replication capability while keeping its antigenic. Previous studies of reported that gamma radiation, a dose of $5.9 \mathrm{kGy}$, inhibited $S$. aureus capability of replication.

In conclusion, 7 KGy the electrophoretic protein profile of $S$. aureus and this result came in agreement with Tuasikal et al., (2012), who recommended irradiated producing base material for mastitis vaccine.
Inactivation of microorganisms by irradiation comes from the inhibition of DNA repair mechanism by increased energy demand of homeostasis on the cell (Hong et al., 2008). Resulting in typical morphological and biochemical changes including nuclear chromatin condensation, cell shrinking, blabbing of the cytoplasmic membrane, break-up of DNA and the final cell fragmentation into apoptotic bodies (Wyllie et al., 1984).

In the current, the comet assay appears to be an appropriate tool to estimate DNA base damage in cells exposed to different doses of ionizing radiation produces a variety of DNA damage types and degrees. The comet assay avoids the induction of artefactual DNA oxidation that occurs in most analytical cells. This seems to come in accordance with the study of Pouget et al., (1999), who used this approach in order to measure DNA damage levels in $S$. aureus exposed to $\gamma$-radiation and found that the comet assay provides a mean to measure base damage without DNA extraction. The study also recommended using comet assay to measure DNA damage level of irradiated $S$. aureus. The assay allows the simultaneous detection of strand breaks after exposure to different radiation doses.

In order to estimate DNA damage levels within the range of doses compatible with the application of the comet assay (from 0 to $9 \mathrm{kGy}$ ), it was found that the DNA percent of change was less than 50\% within the used doses $(0-7 \mathrm{kGy})$. On the other hand, protein analysis by SDS-PAGE revealed that, radiation doses up to $7 \mathrm{KGy}$ caused this results pointed to $7 \mathrm{KGy}$ as the proper irradiation dose to be used for 
inactivation of $S$. aureus with minimum DNA and protein damage effect. The DNA resistance to ionizing radiation deleterious effects in the viable cells compared to free (extracted) DNA for the presence of low molecular mass scavengers of free radicals, antioxidant defense system that mop up free radicals in cells, also to physical protection of DNA by packaging in cells, and cellular repair system of damaged DNA (Hall and Giaccia, 2006).

From previous studies, S. aureus exposed to $5.9 \mathrm{kGy}$ failed to growth. Irradiated $S$. aureus vaccine elicits anti-S. aureus specific antibodies reducing $S$. aureus colonization in the kidneys and skin (Ho Seong Seo, 2015).

In order to evaluate stimulatory effect of attenuated $S$. aureus, different immunological parameters were evaluated in female mice inoculated with irradiated $S$. aureus. Bacterial pathogenicity in the case of $S$. aureus is multifactorial. S. aureus possesses a number of potential virulence factors including cell wall-associated and secreted proteins, which especially cause immunogenic and toxic injuries (Parker, 2017).

Our results showed marked activation of the immune system of female mice represented in significant elevation in mRNA levels of TLR-2 and iNOS and the protein intensity of signal transduction MAPK and Pi3K in the liver and serum levels of inflammatory markers IL-1 $\beta$ and TGF - $\beta 1$ with significant reduction in IL-10 level.

From the presented immunological results, it was obvious that, the level of the
TLR2 showed a remarkable decrease in the challenged mice that were previously inoculated by the non-irradiated S.aureus, then it reached to its highest levels in the challenged mice that were previously inoculated with the irradiated S.aureus, and this result may support the protection role of the irradiated S.aureus in the challenged mice. Meanwhile, TLR2 reached to its highest levels in the challenged mice at a dose of 9 followed by $8 \mathrm{KGy}$, and the least was at the dose $7 \mathrm{KGy}$. An explanation for these results was offered by Knuefermann, (2004) who referred it to the protective effect of the $S$. aureus treated by lower dose of radiation but the higher dose of radiation destroyed the whole bacteria leading to infection of the mice when subjected to the challenge dose of the $S$. aureus leading to increasing the level of the TLR2 as it is a key sensor for detecting $S$. aureus invasion.

Interleukins (ILs) are a group of cytokines (secreted proteins and signal molecules) that were first seen to be expressed by white blood cells (leukocytes). The function of the immune system depends in a large part on interleukins. The majority of interleukins are synthesized by helper CD4 T lymphocytes, as well as through monocytes, macrophages, and endothelial cells. They promote the development and differentiation of $\mathrm{T}$ and $\mathrm{B}$ lymphocytes, and hematopoietic cells (Ben et al., 2011).

IL-10 as it has profound clinical value, especially during vaccinations (Jinhai et al., 2012) and essential for efficient elimination of bacteria and thereby for protection against $S$. aureus infection as it is a factor produced by mouse $\mathrm{T}$ helper type 2 cells 
which inhibit Th1 cytokine synthesis acting as an anti-inflammatory molecule and subsequently down-regulates cell mediated immune functions to enhance the bacterial clearance (Gjertsson et al., 2002).

In the on-going study, the challenge of mice which are previously inoculated by the irradiated $S$. aureus resulted in more enhancements in IL-10 expression in mice inoculated by $7 \mathrm{KGy}$ gamma rays as it recorded 109.02 in comparison to other groups which means more protection. Similar observations were recorded by Ewa et al., (2018), who assured more protection levels of the IL-10 with innate and adaptive immune responses. At the same time, Leech et al., (2017) reported that Staphylococcus aureus has previously been shown to manipulate the IL-10 response as a mechanism of immune evasion during chronic systemic and biofilm models of infection. They referred the detrimental role of IL-10 production to its facilitating effect on the bacterial persistence via the same mechanism of controlling pro-inflammatory $\mathrm{T}$ cell responses. Their findings also demonstrated that induction of IL-10 has a major influence on disease outcome after $S$. aureus challenge (i.e. Too little IL-10 may tend toward fatal host-mediated pathology through excessive activation of $\mathrm{T}$ cells and associated phagocyte-mediated damage).

Fowler and Proctor, (2014) stated that, IL-1 $\beta$ level served as a biomarker for vaccine efficacy as the protective vaccine can promote its production. They also added that, the low level of IL1 $\beta$ can be used as an indicator for low vaccine potency. These data may come in agreement and give an explanation to the obtained results as when the experimental groups were vaccinated by the irradiated $S$. aureus then challenged by the virulent one, the level of IL-1 $\beta$ was changed in comparison to the control group.

iNOS induced in the spleens and kidneys of $S$. aureus-infected mice for protection of mice against $S$. aureus infection. When mice were infected with a challenge dose of $S$. aureus, the expression of iNOS mRNA in the spleens and kidneys was already induced at $3 \mathrm{~h}$ post infection and persisted thereafter. So, higher level of iNOS means higher level of protection against S. aureus (Sanae et al., 1998).The obtained results showed that, iNOs recorded its highest levels in challenged mice which are previously inoculated by radiated $S$. aureus at a dose of $7 \mathrm{KGy}$ which indicate that the mice are well protected against $S$. aureus infection but the level of iNOs decreased at the mice inoculated by radiated $S$. aureus at higher dose of radiation (8 and 9 KGy). These results may be nearly similar to that of the pervious study, who found that the high level of iNOS, which is induced by $S$. aureus infection, is important in the protection of mice against death from $S$. aureus infection. They added that, when mice were infected with a lethal dose of $S$. aureus, iNOS expression is induced immediately after $S$. aureus infection.

TGF- $\beta$ regulateS mammary gland development, as well as mediating mammary gland host innate immune responses to $S$. aureus. (Douglas et al., 2006). In a study of Zhigang et al., (2015), increases in TGF- $\beta$ levels were detected within $40 \mathrm{~h}$ of $S$. aureus vaccination and mediating mammary gland host innate immune responses to $S$. aureus. These data 
explain our results as the TGF- $\beta$ level was increased after challenge of groups inoculated with irradiated S. aureus strain recording high level when compared to the group inoculated with Non-irradiated staph aureus strain. .And this may be due to the role of TGF- $\beta$ in regulating inflammatory processes.

Chen et al., 2013 recorded that, they were released in response to $S$. aureus secreted bacterial exoproducts. In the present study Mitogen activated protein kinase (MAPK) was released in response to $S$. aureus bacterial exoproducts. These results were illustrated by Fuguang et al., (2013) who mentioned that, the MAPK signalling pathways, which regulated the expression of pro-inflammatory cytokines and decreased the susceptibility to mastitis and play a central role during inflammatory responses leading to the release of proinflammatory cytokines, such as IL-1 $\beta$.

(PI3Ks) are a family of signaling enzymes that regulate a variety of important cellular functions, including growth, cell cycle progression, apoptosis, migration, metabolism and vesicular trafficking (Engelman et al., 2006). In our investigation the increased level of phosphoinositide 3 kinase (PI3K) after challenge with virulent $S$. aureus strain indicated prevention of $S$. aureus internalization and powerful vaccination effect (Adam et al., 2015).

The findings in the present study demonstrated that the exposure of $S$. aureus to gamma radiation at a dose of $7 \mathrm{KGy}$ is a suitable method for production of $S$. aureus inactivated safe potent vaccine with low DNA damage, no protein profile alteration and good innate and adaptive immune responses with immunogenic signaling of immune response components (TLR2, IL10, IL1 $\beta$, iNOs, TGF $\beta$, MAPK and PI3K). This approach could expedite vaccine production for emerging and established pathogens for which no protective vaccines exist.

\section{REFERENCES}

Abo-State, M.; El-Gamal, S.; El-Danasory A.; Mabrouk, M.A., 2014. RadioImpact of Gamma Radiation on Pathogenic Bacterial Strains isolated from Rosetta Branch and its Drains of River Nile Water. Middle-East Journal of Scientific Research 21 (5): 776-781

Abo-State, M.A.M. 1996. Study of genetic background and effect of radiation on toxin production by Bacillus cereus. Ph.D. Thesis. Faculty of Science. Cairo University. Egypt.

Adam G. Peres, Camille Stegen, Junbin Li, An Qi Xu, Benoit Levast, Michael G. Surette, Benoit Cousineau, Martin Desrosiers, Joaqun Madrenasb, 2015. Uncoupling of Pro- and AntiInflammatory Properties of Staphylococcus aureus. Infection and Immunity, Volume 83.

Bradford, M.M. 1976. A Rapid and sensitive method for the quantitation of microgram quantities of protein utilizing the principle of protein-dye binding. Anal. Biochem.; 72:248-254.

Ben Menachem-Zidon, O., Avital, A., BenMenahem, Y., Goshen, I., Kreisel, T., Shmueli, E.M., Segal, M., Ben Hur, T., Yirmiya, R. 2011. Astrocytes support hippocampal-dependent memory and 
long-term potentiation via interleukin-1 signaling. Brain, Behavior, and Immunity, 25 (5): 1008-16.

Blood, D.C., Radostits, O.M. 1989. Mastitis, Veterinary Medicine, 7th Ed. Bailliere, Thindall, Philadelphia 537.

Boreham, D.R.; Dolling, J.A.; Maves, S.R.; Siwarungsun, N.; Mitchel, R.E.J., 2000. Dose-Rate Effects for Apoptosis and Micronucleus Formation in Gamma-Irradiated Human Lymphocytes. Radiation Research 153, 579-586

Brakstad, Odd G., Kjetill Aasbakk, Johan A. Maeland, 1992. Detection of Staphylococcus aureus by Polymerase Chain Reaction Amplification of the nuc Gene. Journal of Clinical Microbiology, p. 1654-1660 Vol. 30, No. 7.

Chen Zhu, Hui Qin, Tao Cheng, Hong-Lue Tan, Yong-Yuan Guo, Si-Feng Shi, De-Sheng Chen, Xian-Long Zhang, 2013. Staphylococcus aureus supernatant induces the release of mouse $\beta$-defensin-14 from osteoblasts via the p38 MAPK and NF- $\kappa B$ pathways. International Journal of Molecular Medicine, 31: 1484-1494.

Chomczynski, P. 1993. A reagent for the single-step simultaneous isolation of RNA, SNA and proteins from cell and tissue samples. Biotechniques 15 (3):532-4,526-7

Chotiah, S., 1993. Animal Disease XXV 45: 15.

Cruikshank, R.; Dugid, J.P.; Morromain, B.P., Swaim, R.H. 1975. Medical
Microbiol.12th ed. vol II, chruchil Livingstone. Edinberg, London and NewYork.

Dane Parker, 2017. Humanized Mouse Models of Staphylococcus aureus infection. Frontiers in Immunology. 8 Article 512:1-6

Dosselli, R., Millioni, R., Puricelli, L., Tessari, P., Arrigoni, G., Franchin, C., Segalla, A., Teardo E., Reddi, E. 2012. Molecular targets of antimicrobial photodynamic therapy identified by a proteomic approach, J. Proteomics, 77, 329-343.

Douglas, D., Bannerman, Max J., Paape Annapoorani Chockalingam, 2006. Staphylococcus aureus intramammary infection elicits increased production of transforming growth factor-a, b1, and b2. Veterinary Immunology and Immunopathology $112,309-315$.

Elena K. Gaidamakova, Ian A. Myles, Dennis P. McDaniel, Cedar J. Fowler, Patricia A. Valdez, Shruti Naik, Manoshi Gayen, Paridhi Gupta, Anuj Sharma, Pamela J Glass, Radha K. Maheshwari, Sandip K. Datta, Michael J. Daly, 2012. Preserving Immunogenicity of Lethally Irradiated Viral and Bacterial Vaccine Epitopes Using a Radio-Protective Mn2+Peptide Complex from Deinococcus. Cell Host Microbe., 12 (1): 117-124.

Engelman, J.A., Lou, J., Cantley, L.C. 2006. The evolution of phosphatidyl 3kinases as regulators of growth and metabolism. Nat. Rev. Genet.; 7:606619. 
Ewa Oleszycka, Sean McCluskey, Fiona A. Sharp1, Natalia Mũnoz-Wolf, Emily Hams, Aoife L. Gorman, Padraic G. Fallon, Ed C. Lavelle, 2018. The vaccine adjuvant alum promotes IL-10 production that suppresses Th1 responses Eur. J. Immunol., 48: 705715.

Fowler V.G. Jr, Proctor, R.A. 2014. Where does a Staphylococcus aureus vaccine stand? Clinical Microbiology and Infection 2014 European Society of Clinical Microbiology and Infectious Disease Clin Microbiol Infect, 20 (Suppl. 5): 66-75.

Fuguang Chen, Bingrun Liu, Dacheng Wang, Lin Wang, Xuming Deng, Chongwei Bi, Ying Xiong, Qianchao Wu, Yiwen Cui, Yong Zhang, Xinlan Li, Ying Wang, Bo Liu, Yongguo Cao, 2014. Role of sortase A in the pathogenesis of Staphylococcus aureus-induced mastitis in mice. FEMS Microbiol Lett, 351: 95-103.

Gjertsson, I., Hultgren, O.H., Tarkowski, A. 2002. Interleukin-10 ameliorates the outcome of Staphylococcus aureus arthritis by promoting bacterial clearance. Clin Exp Immunol, 130: 409-414.

Hall, E.J., Giaccia, A.J. 2006. Radiobiology for the Radiologist, 6th edn. Philadelphia, PA: Lippincott Williams $\&$ Wilkins.

Hewitson, J.P., Hamblin, P.A., Mountford, A.P., 2005. Immunity induced by the radiation-attenuated schistosome vaccine. Parasite Immunol, 27: 271-80.
Ho Seong Seo, 2015. Application of radiation technology in vaccines development. Clinical Experimental Vaccine Research, 4: 145-158.

Hong, Y.H., Park, J.Y., Park, J.H., Chung, M.S., Kwon, K.S., 2008. Inactivation of Enterobacter sakazakii, Bacillus cereus, and Salmonella typhimurium in powdered weaning food by electronbeam irradiation. Radiat Phys Chem 77: 1097-1100.

James Attwatwer, Aniela Wochner, Philipp Holloger, 2013. In-ice evolution of RNA polymerase ribozyme activity. Nat. Chem., 5(12):1011-1018.

Jinhai Wang, Gregory Roderiquez, Michael A., 2012. Norcross Control of Adaptive Immune Responses by Staphylococcus aureus through IL-10, PD-L1, and TLR2 Scientific Reports, 2: 606 .

Kloos, W.E.; Lambe, D.W.; Balows, A.; Hausler, W.J.; Herrmann, K.L.; Isenberg, H.D.; Shadomy, H.J., 1991. Manual of clinical microbiology 5th ed. American Society for Microbiology, Washington DC.

Knuefermann, P., Sakata, Y., Baker, J.S., Huang, C.H., Sekiguchi, K., Hardarson, H.S., Takeuchi, O., Akira, S., Vallejo, J.G., 2004. Toll-like receptor 2 mediates Staphylococcus aureus-induced myocardial dysfunction and cytokine production in the heart. Circulation., 110 (24): 3693-8.

Koneman, W.K.; Allen, S.D.; Janda, W.M.; Schreckenberger, P.C.; Propcop, G.W.; Woods, G.L.; Winn, W.C., 2005. Color 
Atlas and Textbook of Diagnostic Microbiology, 6th ed. LippincottRaven Publisher, Philadelphia, USA.

Laemmli, U.K. 1970. Cleavage of structural proteins during the assembly of head of bacteriophage T4. Nature, 227: 68068.

Lee, M.H.; Arrecubieta, C.; Martin, F.J.; Prince, A.; Borczuk, A.C.; Lowy, F.D., 2010. A post influenza model of Staphylococcus aureus pneumonia. J Infect. Dis. J; 201(4): 508-515.

Leech, J.M., Lacey, K.A., Mulcahy, M.E., Medina, E., McLoughlin, R.M., 2017. IL-10 Plays Opposing Roles during Staphylococcus aureus Systemic and Localized Infections. J Immunol. 198 (6): 2352-2365.

Mac Micking, J.D., Nathan, C., Hom, G., Chartrain, N., Fletcher, D.S., Trumbauer, M., Stevens, K., Xie, Q., Sokol, K., Hutchinson, N., Chen, H., Mudgett, J.S., 1995. Altered responses to bacterial infection and endotoxic shock in mice lacking inducible nitric oxide synthase. Cell.;81: 641-650.

Magnani, D.M., Harms, J.S., Durward, M.A., Splitter, G.A., 2009. Nondividing but metabolically active gamma-irradiated Brucella melitensis is protective against virulent $B$. melitensis challenge in mice. Infect Immun, 77: 51819.

Monday Steven R., Bohach Gregory A., 1999. Use of Multiplex PCR To Detect Classical and Newly Described Pyrogenic Toxin Genes in
Staphylococcal Isolates. J. Clin. Microbiol., 37 (10): 3411-3414.

Morton Reitman, H.R., Tribble, J.R., Leonard Green, 1970. Gamma Irradiated Venezuelan Equine Encephalitis Vaccines. Applied Microbiology, Vol. 19, No. 5: 763-767.

Osman Kamelia M., Ahmed Samir, Enas Gamal, Ahmed Orabi, 2014. Increased milk concentration of nitric oxide and lysozyme is associated with listerial mastitis of different animal species. International Journal of Advanced Research, (2) 3: 185-195.

Parker, D., 2017. Humanized Mouse Models of Staphylococcus aureus Infection. Front Immunol.; 8: 512.

Pfaffl, M.W., 2001. A New mathematical model for relative quantification in real-time RT-PCR. Nucleic Acid Res $1 ; 29(9): e 45$.

Pouget, J.P., Ravanat, J.T., Douki Richard, M.J., Cadet, J., 1999. Measurements of DNA base damage in cells exposed to low doses of gamma radiation: comparison between HPLC-EC and comet assays. Int. J. Rad. Biol., 75: 5158.

Quinn, P.J.; Markey, B.K.; Carter, M.E.; Donelly, W.J.; Leonard, F.C., 2003. Veterinary Microbiology and Microbial Disease. Can Vet J.; 44(12): 986.

Reed, L.J.; Muench, H., 1938. A simple method of estimating 50 percent end points. Am. J. Hyg., 27: 493-497.

Sanae Sasaki, Tomisato Miura, Shinsuke Nishikawa, Kyogo Yamada, Mayuko 
Hirasue, Akio Nakane, 1998. Protective Role of Nitric Oxide in Staphylococcus aureus Infection in Mice. Infection and Immunity, Vol. 66, No. 3: $1017-1022$.

Seegers, H., Fourichon, C., Beaudeau, F., 2003. Production effects related to mastitis and mastitis economics in dairy cattle herds. Vet. Res. 34: 475491.

Singh, N.P., Mccoy, M.T., Tice, R.R., Schneider, E.L. 1988. A simple technique for quantification of low levels of DNA damage in individual cells. Exp. Cell Res., 175: 184.

Tuasikal, B.J., Wibawan, I.W.T., Pasaribu, F.H., Estuningsih, S., 2012. Bacterial Protein Characterization of Streptococcus agalactiae by SDS-page Method for Subclinical Mastitis Irradiated Vaccine Materials in Dairy Cattle Atom Indonesia, Vol. 38 No. 2: $66-70$.

Vasudevan, P., Nair, M.K.M., Annamalai, T.A., Venkitanarayanan, K.S., 2003. Phenotypic and genotypic characterization of bovine mastitis isolates of Staphylococcus aureus for biofilm formation. Vet. Microbiol, 92(1): 179-185.
Voyich, J.M.; Braughton, K.R.; Sturdevant, D.E.; Whitney, A.R.; Said-Salim, B.; Porcella, S.F.; Long, R.D.; Dorward, D.W.; Gardner, D.J.; Kreiswirth, B.N.; Musser, J.M., DeLeo, F.R. 2005. Insights into mechanisms used by Staphylococcus aureus to avoid destruction by human neutrophils. J. Immunol., 175: 3907-3919.

Wyllie, A.H., Morris, R.G., Smith, A.L., Dunlop, D. 1984. Chromatin cleavage in apoptosis: association with condensed chromatin morphology and dependence on macromolecular synthesis. J. Pathol., 142: 67-77.

Yuejuan Zheng, Yang Yang, Yuhu Li, Limin Xu, Yi Wang, Ziyi Guo, Haiyan Song, Muyi Yang, Beier Luo, Aoxiang Zheng, Ping Li, Yan Zhang, Guang Ji, Yizhi Yu, 2013. Ephedrine hydrochloride inhibits PGN-induced inflammatory responses by promoting IL-10 production and decreasing proinflammatory cytokine secretion via the PI3K/Akt/GSK3 $\beta$ pathway. Cell. Mol. Immunol. 10: 330-337.

Zhigang Li, Adam G. Peres, Andreea C. Damian, Joaquín Madrenas, 2015. Immunomodulation and Disease Tolerance to Staphylococcus aureus Pathogens, 4: 793-815. 